\title{
Using Gamma Emissions to Identify Cycles in the Lower Cambrian Monkton Formation (NW Vermont): Implications for Identifying Sea Level Variation on the Iapetus Margin
}

\author{
Henry Maguire', Charlotte Mehrtens ${ }^{1}$, Jonathan Kim², Edwin Romanowicz ${ }^{3}$ \\ ${ }^{1}$ Department of Geology, University of Vermont, Burlington, VT, USA \\ ${ }^{2}$ Vermont State Geological Survey, Montpelier, VT, USA \\ ${ }^{3}$ Department of Earth and Environmental Science, SUNY Plattsburgh, Plattsburgh, NY, USA \\ Email: henry.maguire@ucalgary.ca
}

How to cite this paper: Maguire, H., Mehrtens, C., Kim, J. and Romanowicz, E. (2019) Using Gamma Emissions to Identify Cycles in the Lower Cambrian Monkton Formation (NW Vermont): Implications for Identifying Sea Level Variation on the Iapetus Margin. Open Journal of Geology, 9, 89-108.

https://doi.org/10.4236/ojg.2019.92008

Received: October 28, 2018

Accepted: February 25, 2019

Published: February 28, 2019

Copyright $\odot 2019$ by author(s) and Scientific Research Publishing Inc. This work is licensed under the Creative Commons Attribution International License (CC BY 4.0).

http://creativecommons.org/licenses/by/4.0/

\begin{abstract}
The Monkton Formation is described as a Lower Cambrian regressive sandstone unit containing shallowing-up cycles, called parasequences, which record tidal flat progradation. Spatial variation and limited outcrops of continuous stratigraphy have made it difficult to characterize how cycles change in architecture and thickness through the entirety of the Monkton Formation. This study seeks to identify stratigraphic trends in the parasequence architecture and thickness from the successful recognition of facies in the subsurface, information that will clarify how the sea level changes and impacts accommodation space. New geophysical data allow this research project to explore the stratigraphy of the Monkton at higher levels of resolution than previously achieved. Initial statistical study of gamma ray data from a well through the Monkton suggests that meter-scale parasequences are identifiable in geophysical logs. Using continuous gamma log data, this work identified clastic carbonate ratios from a 1034' deep geothermal well drilled at Champlain College in Burlington, VT. Although cycles were identified in the gamma log, the spatial variation, complexity and variety of parasequence types within the Monkton made it difficult to correlate the sequences with specific environments or changes in sea level. To see if specific architectural elements of parasequences and lithologies could be characterized by gamma values, outcrops of the Monkton were surveyed containing both parasequences and lithologies that were useful paleobathymetric indicators. The survey determined gamma ray patterns and relative values of a common Monkton parasequence representing tidal flat progradation and a carbonate lithology indi-
\end{abstract}


cating an abrupt sea level rise. Gamma data from a second well on the University of Vermont campus, along with accompanying borehole camera video, confirmed that the outcrop survey results could be useful in subsurface interpretations of the Monkton. Intervals representing the parasequences and carbonate lithologies were identified in the Champlain College Well and were combined with the UVM Fleming Well findings to create a composite stratigraphic section of the Monkton. The parasequences and lithologic trends identified in the composite section indicated that, over the entirety of the Monkton, accommodation space decreased. The decrease in accommodation space is interpreted to represent a change in the rate of sea level rise. The Monkton Formation deposition occurred in a transgressive systems tract with varying rates of sea level rise, which implied that the overlying Winooski Formation would represent highstand systems tract deposition.

\section{Keywords}

Cambrian, Sequence Stratigraphy, Parasequence, Vermont Sedimentary Sequence and Monkton

\section{Introduction}

The characterization of parasequences is a key component for interpreting depositional systems and systems tracts in the field of sequence stratigraphy. Parasequences represent the cyclic deposition of a conformable succession of genetically related beds or bedsets bound by a marine flooding surface [1] and the identification of stratigraphic trends in parasequence architecture and thickness is used to clarify how sea level changes and impacts accommodation space [2]. Understanding how sea level fluctuates within a depositional sequence allows for that stratigraphy to be put into the context of systems tracts and sequence stratigraphy.

The Monkton Formation of northwestern Vermont is described as a Lower Cambrian regressive sandstone unit containing shallowing-up cycles (SUCs) recording tidal flat progradation [3] [4]. This heterolithic unit is greater than 300 meters in thickness and is comprised of sand, silt and dolostone [5]. [4] studied this mixed siliciclastic-carbonate unit, identifying facies recording supratidal, intertidal and shallow subtidal deposition which were interpreted to represent prograding tidal flat sedimentation. [4] and later [6] described the unit as being characterized by repeating shallowing-up cycles or parasequences, representing this tidal flat progradation.

Repeating meter-scale shallowing-upward parasequences of mixed siliciclastic-carbonate rocks in the Monkton are identifiable at a variety of outcrops in the Champlain Valley of Vermont. However, spatial variation and limited outcrops of continuous stratigraphy make it difficult to characterize how cycles change in architecture and thickness through the entirety of the unit. [7] col- 
lected gamma log data through a significant portion of Monkton stratigraphy in a 1034' deep geothermal well drilled at Champlain College in Burlington, Vermont and identified cyclic patterns, interpreted as parasequences, in the gamma log data. However, the nature of the mixed siliciclastic-carbonate facies and the depositional complexities in the subtidal, intertidal and supratidal environments of the Monkton made it difficult for the authors to confidently interpret the parasequences in the well log data. Building on their preliminary work, this study has several objectives, including outcrop analysis of gamma emission patterns, analysis of gamma emission and borehole camera data from a second well, and syntheses of these data to identify parasequence architecture trends through the Monkton and using this information to interpret how sea level and accommodation space change.

\section{Geologic Setting}

The Monkton Formation, along with the entirety of the Cambrian stratigraphic sequence in Western Vermont, was deposited on a thermally subsiding tectonically stable shelf along the Laurentian-Iapetus Ocean margin that formed following the breakup of Rodina [8]. Recent work by [9] using paleomagnetic, lithologic and geochronologic data suggests that the breakup of Rodina was complete by $580 \mathrm{Ma}$. The formation of the Laurentian-Iapetus Ocean margin has been constrained between 615 and $580 \mathrm{Ma}$ based on radiometric age determinations of rift-related, Tibbit Hill Formation, basalts that formed in modern Vermont and Southern Quebec at a triple junction associated with the breakup of Rodina [10].

The triple junction, created during rifting, formed three major features that controlled large scale sediment distribution along the Iapetus margin. On the two successfully rifted arms, northwest-striking transform faults offset northeast-striking rift segments including the (convex ocean-ward) New York Promontory and (convex land-ward) Quebec Reentrant features [11]. The failed third arm of the triple juncture forms the $55 \mathrm{~km}$ wide and $700 \mathrm{~km}$ long topographic low known as the Ottawa-Bonnechere aulacogen [12]. The Cambrian sequence in Vermont was deposited on the New York Promontory portion of the shelf. The shallow water Monkton, Cheshire, Dunham, Winooski and Danby Formations make up the Vermont Iapetus shelf units whereas the Parker, Skeels Corners, Rugg Brook and Rockledge Formations represent the basinal environments [13]. These deeper water formations were deposited in a depocenter known as the Franklin Basin located north of Colchester, Vermont [14].

The allochthonous Cambrian stratigraphy found in the Champlain Valley was transported $\sim 80 \mathrm{~km}$ to the west emplaced over Ordovician limestone and shales, on the upper-plate of the Champlain Thrust [15]. Even with this Middle Ordovician displacement of the Champlain Thrust the Cambro-Ordovician stratigraphy in the Champlain Valley has remained relatively undeformed. The outcrop belt of the Vermont Iapetus Shelf units extends from the Franklin Basin to the north, 
southward the length of Vermont. As can be seen on the bedrock geologic map of Vermont [16], this stratigraphy is located on the western limb of broad synclines, to the north the St. Albans Synclinorium and to the south, the Middlebury Synclinorium.

The age of the Monkton is based on biostratigraphic data. Ptychoparia adamsi and Ollenellus zone trilobites present in the Monkton, place the formation's age as Lower Cambrian [17] [18]. The underlying Dunham Dolostone contains Salterella conulata, a Lower Cambrian index fossil [19] correlative with the lower Olenellus trilobite zone. The basal horizons of the Parker Slate, a fine-grained unit deposited in the Franklin Basin, also contain Lower Cambrian age Ollenellus zone trilobites [14] [20], indicating that the Monkton and part of the Parker are correlative. However, upper horizons of the Parker contain trilobites of the Bolaspidella zone of Middle Cambrian age [3]. These authors identify the five missing trilobite zones between Olenellus and Bolaspidella, a gap that occurs in stratigraphy along the Iapetus margin elsewhere in the Appalachians, and which represents a basin-wide unconformity they termed the Hawke Bay Event. Because of this unconformity, it is not clear whether the entire Monkton is Lower Cambrian in age or if it extends into the Middle Cambrian. The overlying Winooski Dolostone is dated as Middle Cambrian on the basis of interbedding with the younger trilobite-bearing Parker Slate.

During the time interval of Monkton deposition, the North American craton was in the early stages of a sea level rise termed the Sauk megasequence by [21]. The Sauk megasequence includes strata from latest Precambrian to Early Ordovician in age, an interval based on its position between an interregional pre-Cambrian conformity and an interregional unconformity at the base of the succeeding Tippecanoe sequence [21] [22]. [23] subdivided the Sauk megasequence into transgressive-regressive cycles termed supersequences and even these are further subdivided into depositional cycles referred to as sequences. [24] recast the terms megasequences, supersequences and sequences in terms of sequence stratigraphy as first, second, and third order cycles, respectively, and estimated their time durations as $50-100 \mathrm{My}, 5$ - $50 \mathrm{My}$ and 0.5 - $5 \mathrm{My}$, respectively.

Several authors made interpretations of sea level fluctuation within the Sauk transgression in the Northern Appalachians. The Hawke Bay unconformity described by [3] marks the boundary between the Sauk I and II super sequences [25], which in the Vermont Cambrian sedimentary sequence is marked by the unconformity separating the Dunham Dolostone and the overlying Monkton Formation. In addition to [3], [26] suggested that the fluctuating sea levels influenced basin aerobic and disaerobic cycles on the Iapetan continental slope, producing varying coloration of shale units which they interpreted as recording two deepening in these late Early Cambrian deep water deposits.

\section{Monkton Formation}

The greater than 300 meter thick mixed siliciclastic-carbonate Monkton Forma- 
tion was studied by [4] and [6], both of whom identified facies recording supratidal, intertidal and shallow subtidal deposition. More recent work by [27] identified a fluvial facies of the Monkton in erosional contact with the Dunham Dolostone; the contact between these two units is commonly in a covered interval.

Although the first detailed description and thickness estimate of the Monkton was done by [5], it was [4] who characterized the cyclic nature of deposition in the Monkton Formation. He identified two repeating types of sedimentary cycles within Monkton Formation (Figure 1). The first of these is a mixed siliciclastic-carbonate cycle that is more carbonate-rich towards the top of the cycle. The

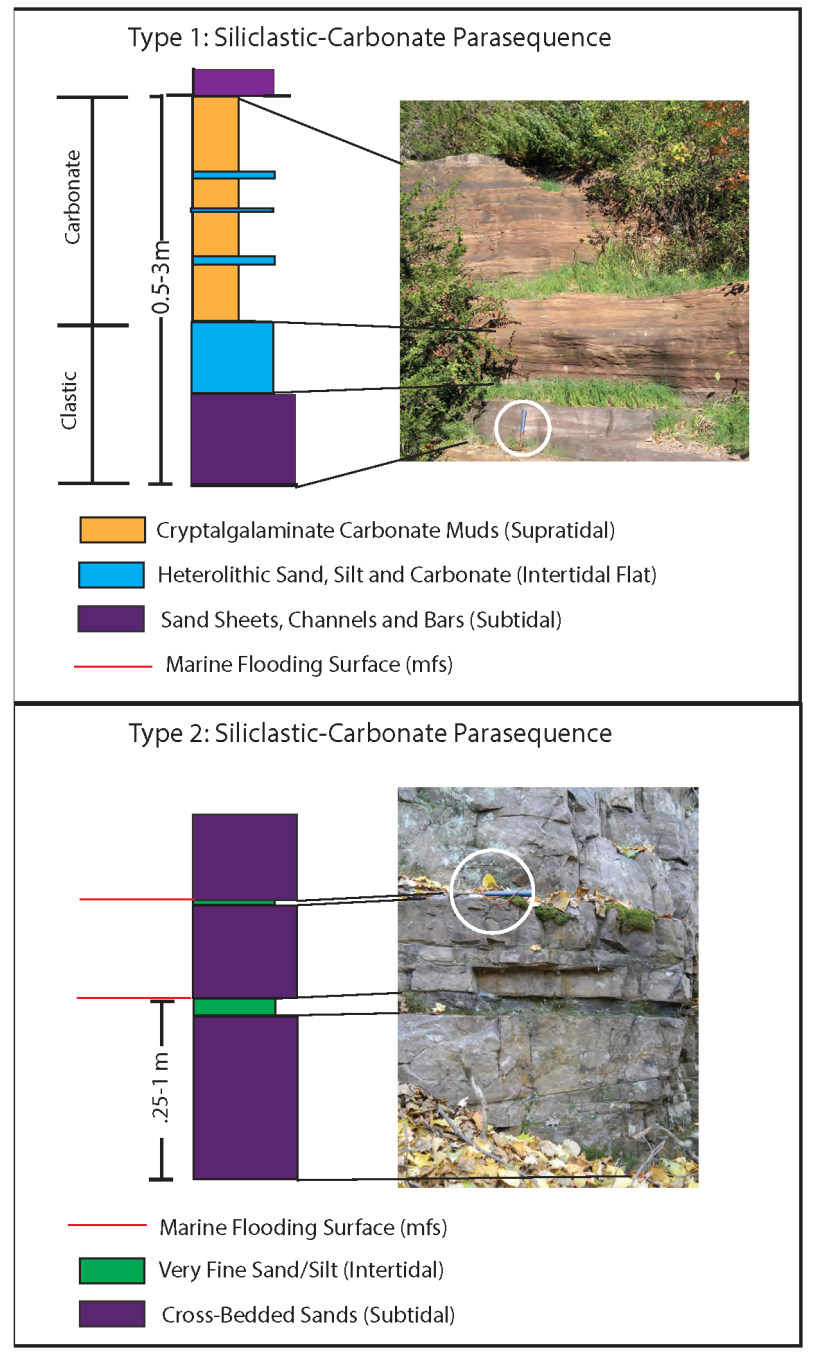

Figure 1. Stratigraphic columns and corresponding outcrop examples of Rahmanian's Type 1 and Type 2 parasequences [4]. The Type 1 cycle architecture example is from Redstone Quarry and represents the transition from subtidal and tidal channel deposits at the base into intertidal heterolotihic deposits and eventually towards a carbonate dominated intertidal-supratidal deposit at the top. The Type 2 cycle architecture illustrated is from Pease Mountain and represents the transition from a subtidal bar and tidal channel deposit moving up into a mixedsand and mud intertidal flat deposit. The red lines on the columns mark the maximum flooding services at the top of the parasequences. Circled in white are rock hammers for scale. 
cycle is interpreted to record the transition from subtidal and channel system facies to a carbonate dominated intertidal-supratidal facies. This mixed siliciclastic-carbonate carbonate cycle identified by [4] is useful in making sea level interpretations because the carbonate facies characteristic of the peritidal setting makes an excellent paleobathymetric indicator. The second cycle is siliciclastic-dominated and is interpreted to have formed in a subtidal bar and tidal channel environment moving stratigraphically upwards into mixed sand and mud intertidal flat. [4] interpreted the down slope pinch out of the tidal flat to represent overall regressive sedimentation recording tidal flat progradation.

Using the terminology of sequence stratigraphy, shallowing-up cycles is also called parasequences. Parasequences can be considered a fourth or fifth order sea level cycles which represents durations of between 0.01 and $0.5 \mathrm{Ma}$ [24]. The cyclic sediment deposition creating these parasequences are commonly identified in core and well logs and are often used by stratigraphers for correlation between wells. Parasequence sets describe successions of parasequences that form a distinctive stacking pattern [28] and they are used to define systems tracts [29].

Cyclic deposition of parasequences can develop if accommodation space is sequentially created. This can happen as a result of external processes, such as sea level change, in which case the driving mechanism is termed allocyclic, or internal processes related to lateral facies migration, termed autocyclic processes. [30] suggested that autocyclic processes occur within a particular depositional setting, such as a fluvial system, and their effects tend to be local and, in geologic terms, instantaneous. They are described as aperiodic because they generally occur randomly in time and space [31].

The Type 1 cycle recording the progradation of tidal flat sediments is interpreted to record allocyclic deposition because the space needed to produce the vertical accretion of such shallow water sediment implies that space was created through repeated sea level changes (Figure 1) [4]. Rahmanian's Type 2 subtidal sandstone cycles, associated with the lateral migration of tidal channels and sand bars, would be the product of autocyclic processes, however these may also occur during sea level fluctuation (Figure 1). For this study we are most interested in the cycles produced by the prograding tidal flat deposits (Rahmanian's Type 1), because the depositional environments represented by these cycles are accurate bathymetric (sea level) indicators.

Table 1 summarizes the five lithofacies of the Monkton that define bathymetric and sea level conditions. Lithofacies 1 - 3 represent the range of environments (subtidal, intertidal and supratidal) found within Type 1 and 2 cycles, while lithofacies 4 and 5 indicate deposition under specific environmental conditions; lithofacies 4 describes a clear water platform carbonate that would only form when there is little siliciclastic input and this lithology is interpreted to have been deposited during a rapid base level rise. These flooding events trap clastic sediment in more proximal alluvial systems, allowing for the return to 
Table 1. Summary of lithologies identified in outcrop and subsurface studies. The depositional environments of these lithologies are identified by their sedimentary structures. These identified depositional environments make these lithologies ideal bathymetric indicators. The expected gamma values of these lithologies within the well log are a general guide and not absolute in interpretations, depending on the thickness of the bed and the adjacent lithologies this can vary.

\begin{tabular}{|c|c|c|c|c|}
\hline Lithofacies & Lithologies & Sedimentary Structures & $\begin{array}{l}\text { Depositional } \\
\text { Environment }\end{array}$ & $\begin{array}{c}\text { Expected Well Log } \\
\text { Gamma Values }\end{array}$ \\
\hline 1 & $\begin{array}{l}\text { Moderately to well } \\
\text { sorted sandstone, } \\
\text { variably dolomitic }\end{array}$ & $\begin{array}{c}\text { Trough and tabular, } \\
\text { herringbone cross } \\
\text { stratification, horizontal } \\
\text { laminations }\end{array}$ & Subtidal sand bars & $\sim 100-200$ (cps) \\
\hline 2 & $\begin{array}{c}\text { Sandstone, siltstone, } \\
\text { dolostone }\end{array}$ & $\begin{array}{l}\text { Ripples, mudcracks, } \\
\text { bioturbation, flaser } \\
\text { bedding }\end{array}$ & Intertidal sand flats & $\sim 150-250$ (cps) \\
\hline 3 & Dolostone, siltstone & $\begin{array}{l}\text { Cryptalgalaminations, } \\
\text { rip up clasts }\end{array}$ & Tidal ponds & $\sim 60-150$ (cps) \\
\hline 4 & $\begin{array}{l}\text { Sucrosic dolostone, } \\
\text { arenaceous dolostone }\end{array}$ & $\begin{array}{l}\text { Uncommonly rippled or } \\
\text { cross stratified }\end{array}$ & Subtidal shelf & $<\sim 60$ (cps) \\
\hline 5 & $\begin{array}{l}\text { Poorly sorted arkosic } \\
\text { sandstone, abundant } \\
\text { accessory minerals }\end{array}$ & $\begin{array}{l}\text { Dewatering structures, } \\
\text { load casts and burrows }\end{array}$ & $\begin{array}{l}\text { "event bed", rapidly } \\
\text { deposited unsorted } \\
\text { sediment on the } \\
\text { tidal flat }\end{array}$ & $>\sim 250$ (cps) \\
\hline
\end{tabular}

clear water carbonate deposition on the shelf. Lithofacies 5 is poorly sorted arkosic sandstone containing abundant accessory minerals and displaying features such as dewatering and load structures (Figure 2). This lithofacies is interpreted as an event bed related to rapid deposition from storm-generated sediment discharge onto the tidal flat. Though lithofacies 5 is not necessarily a bathymetric indicator, the ample accessory minerals were found to have a unique gamma signature.

Because of the association with different gamma emissions from different lithologies, characterizing the gamma signatures of the facies representing these environments and of the parasequences they create would lead to successful recognition of facies in the subsurface. Wells drilled through the Monkton provide the thickest continuous section of Monkton stratigraphy and allowed us to identify stratigraphic trends in parasequence architecture. Such trends in architecture and thickness can clarify how the sea level changed and impacted accommodation space through Monkton deposition. However, in order to confirm that the lithofacies within a parasequence can be accurately recognized in a well log, outcrop examples of parasequences were logged using a methodology described below.

\section{Survey Methods}

\subsection{Outcrop Survey}

Outcrops were chosen where parasequences and distinct lithologies within the Monkton were well exposed and easily identified and where the relative position 


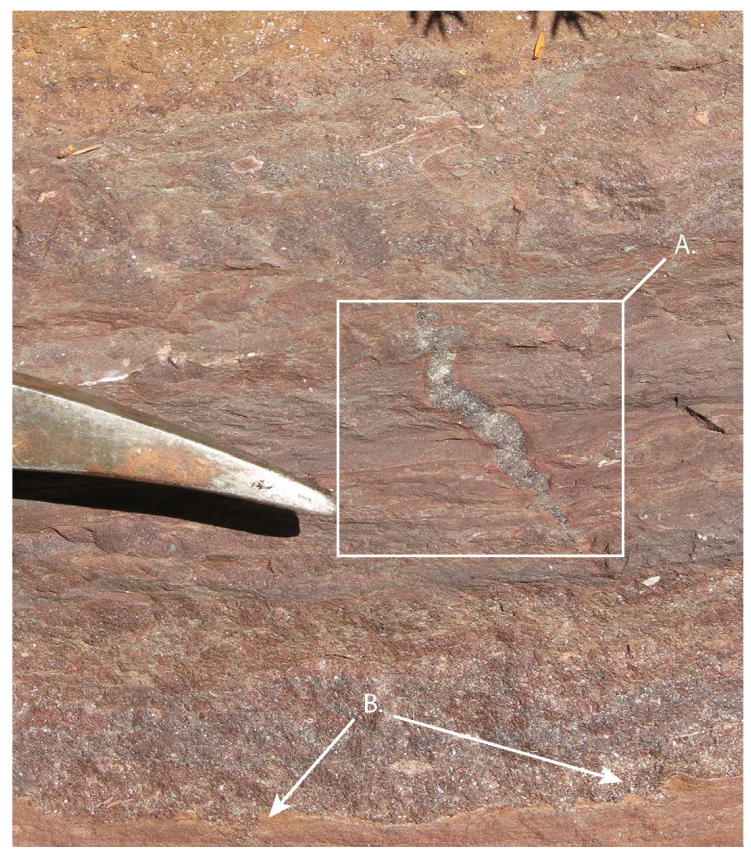

Figure 2. Outcrop photograph of lithofacies 5 from Redstone Quarry. This lithofacies is poorly sorted arkosic sandstone with abundant accessory minerals. Dewatering (A) and load cast structures (B) are labeled. Both are interpreted to record rapid sedimentation in a shallow subtidal envrionemnt. The hammer head is for scale and its length is approximately $8 \mathrm{~cm}$.

of the exposure relative to the base of the overlying Winooski Formation is known. Gamma emission data collection was completed through stratigraphic intervals at three localities: Redstone Quarry, Salmon Hole, and at Pease Mountain (Figure 3). Gamma ray data was collected in counts per second (cps) using a Radiation Solutions hand held gamma-ray spectrometer (RS-230 BGO Super-SPEC).

In order to mimic the continuous curve data collection in gamma well log data, surveys were completed by hand-held logging in 5 and $10 \mathrm{~cm}$ increments, collecting data through the thickness of the stratigraphy. Readings were taken for one minute at each position and then averaged to get a single gamma (cps) value at that point. With this data, a continuous curve of gamma emission through the interval of stratigraphy was produced by connecting these points.

While of the focus of data collection was from the parasequences in the Monkton, the unit also contains lithologies (ex, lithofacies 5) that are not part of a cycle. Like the continuous survey through a cycle, readings were taken for one minute and then averaged to get a gamma value in (cps) for these lithologies. The gamma-ray spectrometer was positioned as much in the middle of the bed of interest as possible. These values were not used to produce any sort of curve, just to identify relative gamma values for certain lithofacies.

\subsection{Well Survey}

Both the Fleming and the previously logged Champlain College wells are located 


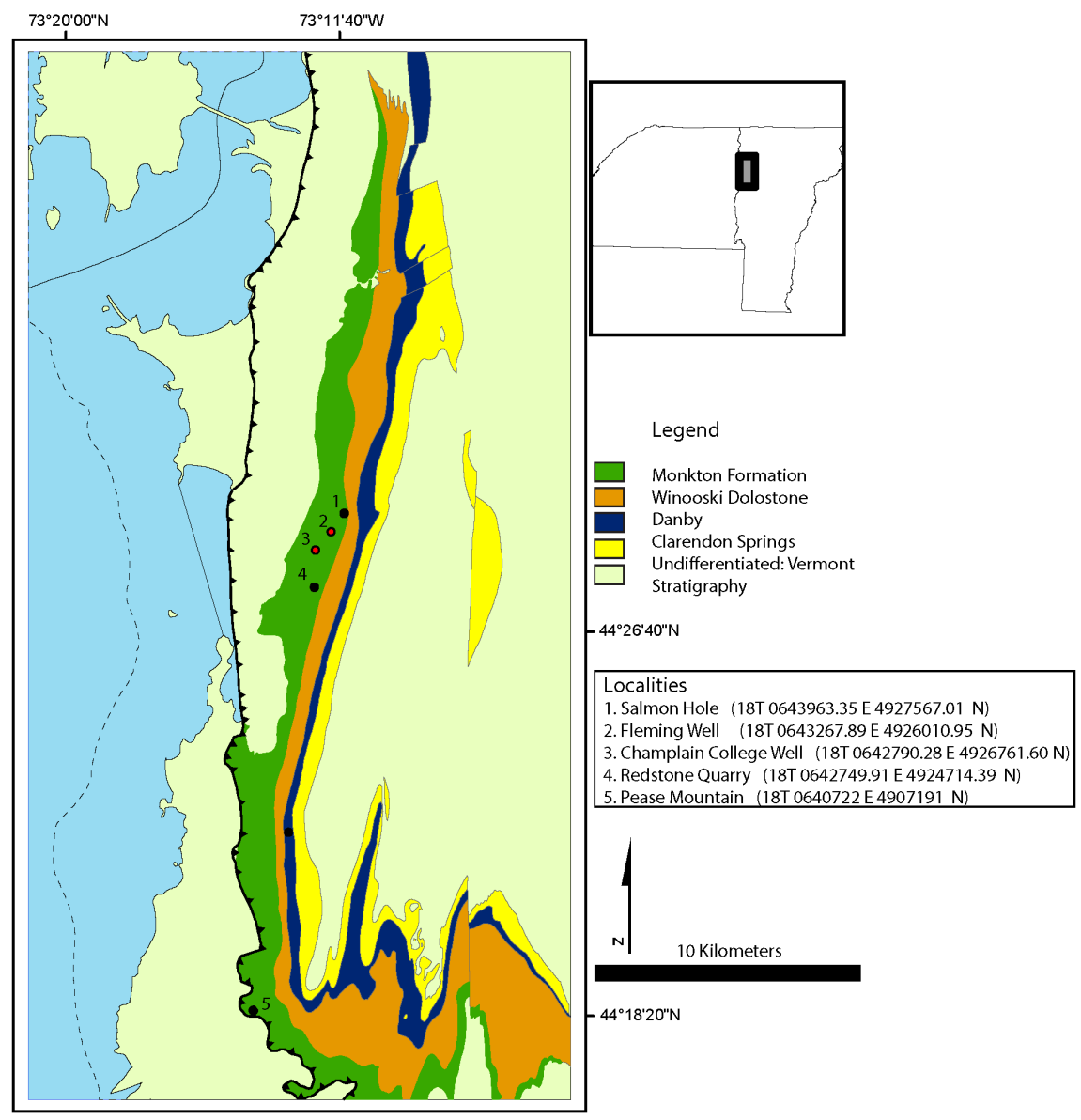

Figure 3. Simplified bedrock geologic map of Vermont showing localities for wells and outcrop studies within the Monkton Formation. Base map is the bedrock geologic map of Vermont [16].

within the city limits of Burlington, Vermont. The Fleming well is a former teaching well located on the University of Vermont campus (Figure 3) that was drilled in 1996. The total depth of the well is $\sim 91$ meters with the first 41 meters in casing. Gamma data was collected using a Mount Sopris Instruments 2PGA-1000 POLY-GAMMA PROBE taking readings in $5 \mathrm{~cm}$ increments. The well was logged twice with the gamma tool. A caliper tool was also used to log the diameter of the entire well to be used in open-holewell water corrections. Water is located within the well at $\sim 68$ meters in depth. Additionally, a downhole camera was used to get imagery of the stratigraphy through the uncased portion of the well. The previously logged Champlain College data was acquired from Jon Kim of the Vermont Geologic Survey. This well was logged by Jon Kim and Edwin Romanowicz (S.U.N.Y Plattsburgh) in 2012 using the same Mount Sopris Instruments 2PGA-1000 POLY-GAMMA PROBE taking reading in $3 \mathrm{~cm}$ increments. The raw and filtered data for both the Fleming well and Champlain College wells can be found in [32].

Both the wells and outcrops in the Burlington area could be correlated using strike and dip data for bedding and DEM elevation data. Using strike, dip and 
distance data, the stratigraphic sections of Fleming and Champlain College wells and the outcrops at Redstone Quarry and the Salmon Hole were hung from the contact of the overlying Winooski Formation (Figure 4). From this it was determined that $\sim 12 \mathrm{~m}$ of uncased stratigraphy overlapped between the two wells and that the Salmon Hole and Redstone Quarry outcrops lay within the casing of the Fleming well.

In order to test the physical correlation between the two wells a statistical method was also used. The goal of this statistical method was to compare the gamma curve from the portions of the Fleming and Champlain wells that overlap, according to physical stratigraphy. A statistical test would confirm if our original physical correlation was statistically viable or if there are other correlations that are more likely. A correlation coefficient, or linear dependence of two variables or sets of data, was used to see how strong the correlation is of an interval of the Fleming well gamma data to an interval of the Champlain College well gamma data. To do this, the portion of the Fleming well that overlaps (according to our physical correlation) was broken into thirds of approximately 4 meters in thickness to create manageable intervals of comparison. The correlation coefficient was calculated sequentially descending through the Champlain College well. This process was repeated for each of the three segmented intervals through the

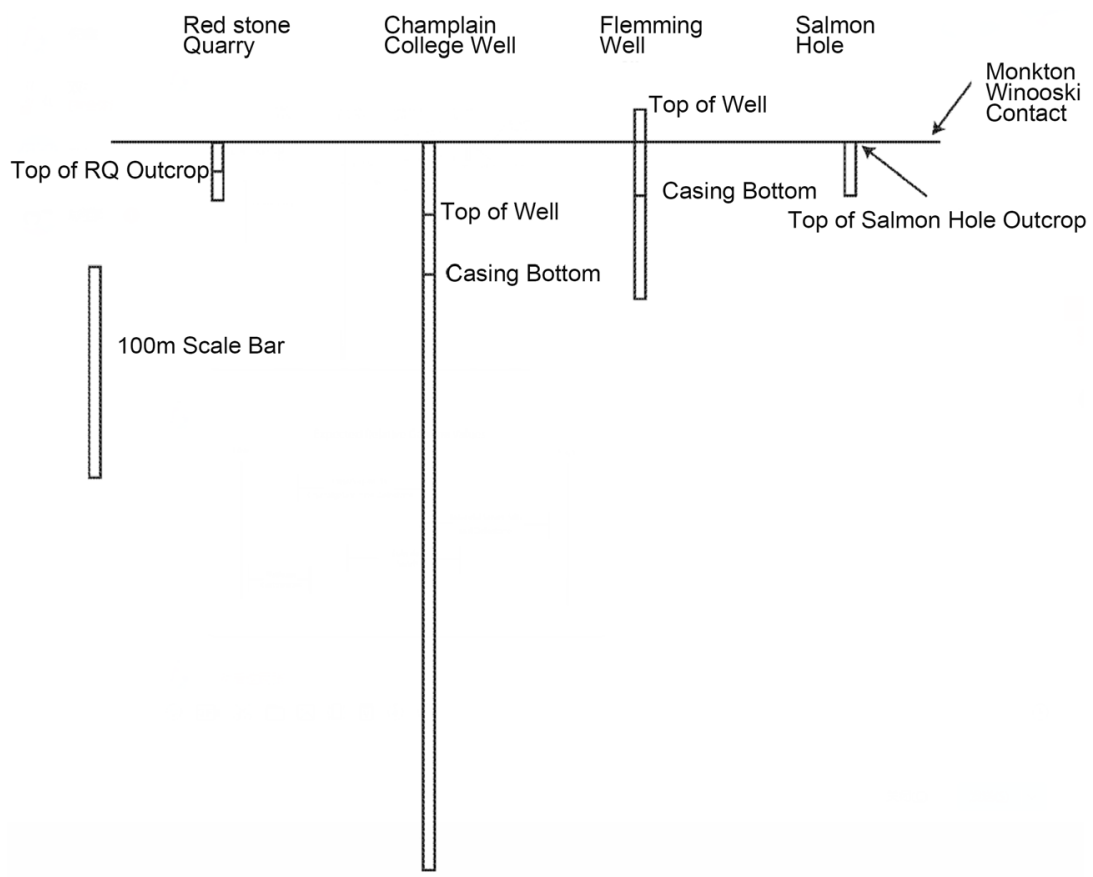

Figure 4. Relationships between Monkton stratigraphic intervals from wells and outcrops. The stratigraphic intervals were hung with their relationship to the contact between the Winooski and Monkton Formations. These relationships were identified using elevation and distance data from DEM maps and dip data from two outcrops to the north and south of the wells. The attitude measured from the two outcrops was on bedding planes and a mean strike and dip of $15^{\circ}$ and $7^{\circ}$ was determined, respectively. The intervals of stratigraphy could then be projected with respect to their relationship with the Winooski Monkton contact. 
entire Champlain College well. Results indicate the physical correlation between wells has a high $(\sim 0.7)$ statistically significant correlation for each of the three segments, suggesting that the physical correlation is correct. However, there were other levels within the Champlain College well that also had a high statistical correlation coefficient to the Fleming well. If these alternative correlations are accepted it would require a more complicated scenario. The closest and least complicated alternative position was located between 50 and $55 \mathrm{~m}$ depth in the Champlain College well. For this to be possible the two wells could be offset by a high angle fault with a displacement of $23.5 \mathrm{~m}$. Additionally, a bedding attitude change of 3 degrees between the two wells could also explain the alternative correlation. A broad fold that changes dip magnitude a few degrees over 0.61 miles is plausible, however there is no evidence of this. Neither is there evidence of faulting. Finally, because of the repetitive occurrence of cycles with a similar architecture and gamma values the statistically significant correlation coefficients may occur simply because of in a segment of a stratigraphic sequence it wouldn't be possible to distinguish one cycle from another; a thicker record would be needed. For these reasons we believe that the physical correlation shown in Figure 4 is correct. However, the alternative interpretations cannot be completely ruled out. Based on the original correlation as a whole, nearly 350 meters of Monkton stratigraphy was represented in our well and outcrop data

\section{Data Processing Methods}

\subsection{Well Log Filtering}

The intensity of gamma emissions is controlled by the abundance of radioactivity-emitting minerals present in different lithologies, however gamma log data is subject to random noise due to the counting statistics other sources of error and because radioactive processes are inherently subject to statistical variation [33]. Additionally, variation in gamma log data can vary between logs due to logging speed and tool calibration [34].

A series of data filtering steps were taken to remove unusable data, adjust for water within the wells and to reduce noise. The same filtering procedures were done on both wells. All data from in well casings was deemed unusable and omitted from discussions. Though attenuation from well casing can be adjusted for, data in both well casing was omitted from this study because of the limited amounts of bedrock stratigraphy within them. Both the Champlain College and Fleming wells contained water below $\sim 56$ and $\sim 68$ meters, respectively. An industry standard correction factor for all points, within open water filled holes, based on hole diameter was applied to these portions of the wells [35].

Smoothing of the raw gamma emission data was completed to suppress statistical noise and account for variation in vertical resolution inherent to gamma logging tools. Two assumptions about borehole gamma logging were used in setting the parameters for filtering. First, the vertical resolution of a gamma probe is between 30 and $60 \mathrm{~cm}$ which means that any gamma data point could be 
measuring emissions over this interval of well stratigraphy. Second, across this vertical resolution readings are being picked up in a symmetrical probability distribution relative to the center of the sensor [36] [37] [38]. To account for these two factors a moving average was taken vertically over $\sim 40 \mathrm{~cm}$ of data points in the well log and weighted over a symmetrical distribution. The symmetrical distribution curve used was a Hann Curve, such that values in the center of the data points being averaged were weighted more in the moving average than those at the top and bottom or, in other words, the gamma probe, over the vertical resolution, was less influenced by rocks further away from it than by the rocks directly adjacent to it.

\subsection{Outcrop Survey}

From outcrop data, four endmember Monkton lithofacies were identified to be most useful in subsurface interpretations: 1) clear water subtidal platform carbonates; 2) a variety of subtidal sandstones and sandy dolostones; 3) the intertidal sand, silts and dolostones representative of the tidal flat; 4) supratidal/high intertidal cryptalgal laminate dolostone. The relative gamma values measured from these lithologies are shown in Figure 5.

The results of the survey from Redstone Quarry can be seen in Figure 6 which illustrates the observed gamma ray curve from two mixed siliciclastic-carbonate parasequences. Both cycles represent the transition from the clastic dominated intertidal sandstones and siltstones vertically into the carbonate dominated supratidal dolostones. The abrupt lithologic change at the base of a cycle, transitioning from carbonate to siliciclastic lithologies, is interpreted as the marine flooding surface (MFS) and can be identified from the abrupt gamma value increase. The higher gamma value holds steady in the heterolithic intertidal lithology until it gradually decreases in value moving up in the stratigraphy. This gradual decrease represents the gradational transition into the supratidal cryptalgal laminate dolostone. Comparing the two cycles illustrated in Figure 6 illustrates

Expected Relative Gamma Values

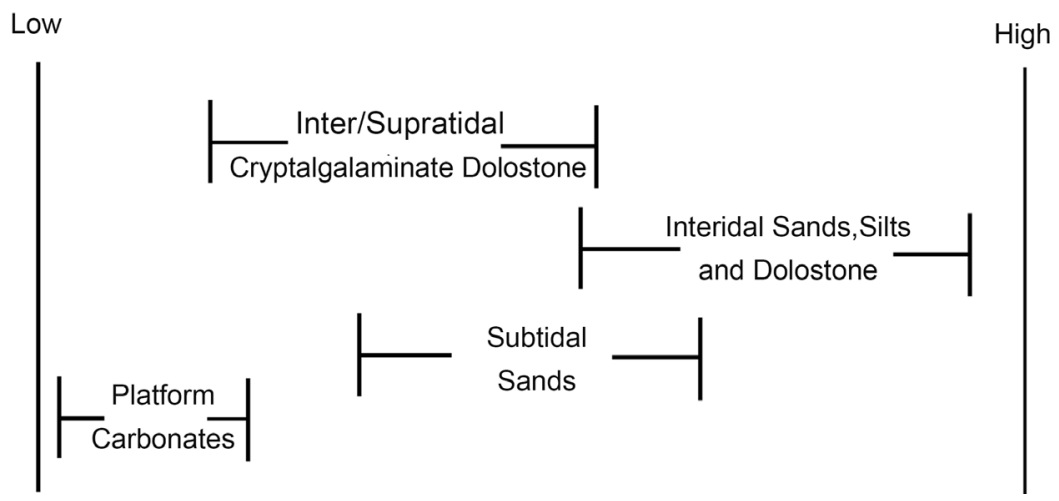

Figure 5. Expected relative gamma values for lithologies used in subsurface interpretations. These are not assigned exact gamma values but show the relative overlap and relationship between them. Because of the overlap it is also essential that the gamma ray curve shape must also be incorporated into interpretations of gamma emission patterns. 

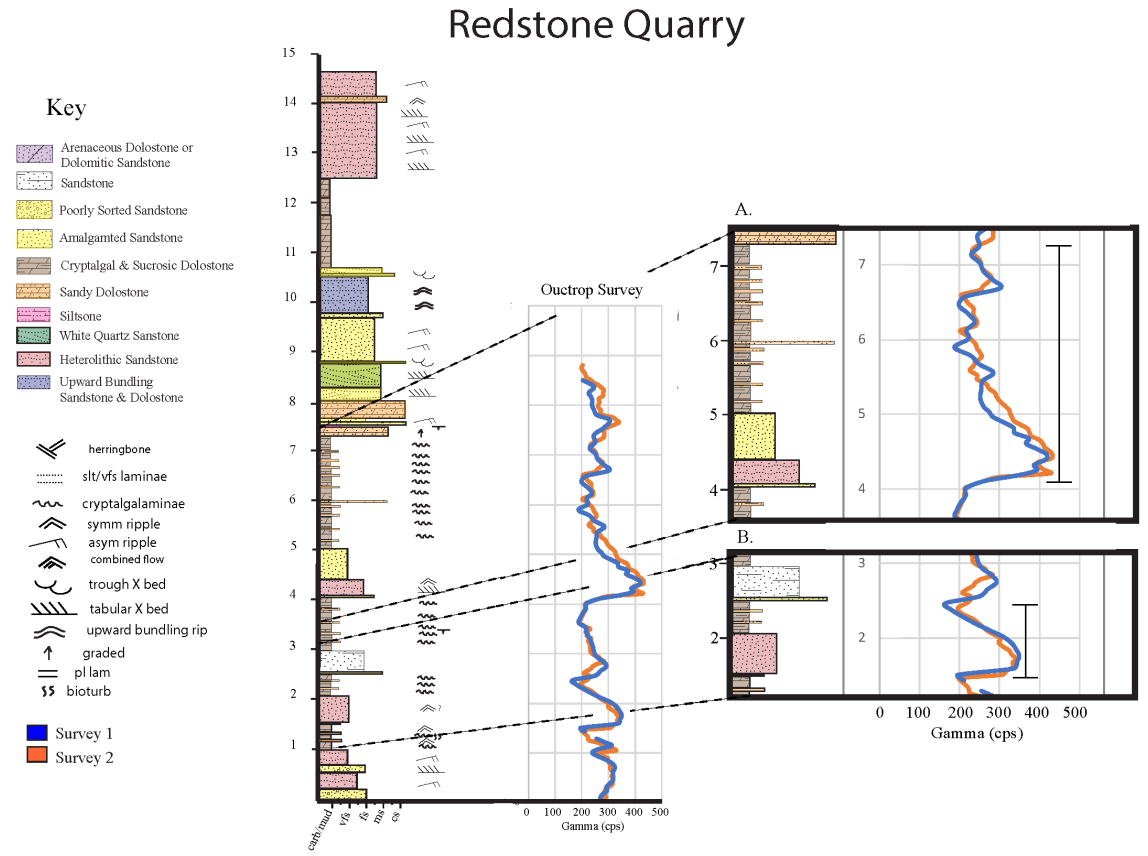

Figure 6. Redstone Quarry stratigraphic column with outcrop survey gamma results. Survey 1 was completed in $10 \mathrm{~cm}$ increments and survey 2 in $5 \mathrm{~cm}$. Outcrop survey results of intervals representing two of the Rahmanian's Type 1 parasequences are highlighted [4]. Both cycles have an abrupt boundary on the bottom of the gamma curve and then gradually grades upward through the cycle. Example A is a thicker parasequence and as a result the interbedding of lithologies can be seen in the jagged gamma emission curve. The detailed jagged curve representing interbedded silt and cryptalgal dolostone is not seen in example B, the nature of the survey would not necessarly pick up the interbedding in thin interval. It should be noted that neither of the examples illustrated here contain a subtidal basal unit that is seen elsewhere.

that the thicker cycles show more internal variation in gamma emission data; the serrated shape of the lower curve represents the interbedding of sandstone and siltstone lithologies that is not developed in the thinner parasequence.

\subsection{Fleming Well}

The relative gamma values for the lithologies and the gamma curve shapes predicted for cycles, based on outcrop results, were used to identify the parasequences and platform carbonate intervals within the Fleming Well gamma log. The gamma curve interpretations in the Fleming well were confirmed using the borehole camera imagery within the well log, details of which can be found in [32]. Results confirm what was observed from the outcrop logging: the platform dolostones have the lowest gamma values while the interbedded sands, silts, and dolostones recording tidal flat environments are characterized by the highest relative gamma values. The cryptalgal laminate dolostone lithology is characterized by a lower-middle gamma value.

\subsection{Champlain College Well}

The Fleming and Champlain College Wells were both logged at different speeds 
and sampling intervals which lead to overall variation in absolute gamma emission values. Correlations, in the $\sim 11 \mathrm{~m}$ of uncased overlapping stratigraphy between the peaks in the gamma logs identified that the Champlain College Well gamma peak values were $\sim 25$ (cps) higher on average than the Fleming Well peak values. This slightly higher gamma value was factored into interpretations within the Champlain College Well.

Unlike the Fleming Well, the Champlain College Well did not have borehole camera data to help identify subsurface characteristics. The ability to recognize parasequences and certain lithologies was developed from the analysis of the Fleming well. The Champlain College Well was analyzed using the same approach as the Fleming well. The intertidal to supratidal parasequence illustrated in Figure 6 and described from the Fleming Well was the easiest cycles to recognize in the Champlain Well. The characteristically low gamma values of significant dolostone horizons, interpreted as subtidal platform carbonates, are also clearly identifiable.

\section{Results}

Using the gamma curves and bedding attitudes the Fleming and Champlain College wells were correlated and their positions with respect to the Monkton/Winooski contact determined. Parasequences that record inter-to supratidal shallowing up cycles and thicker subtidal platform dolostone horizons were identified and compiled and plotted relative to their position below the Monkton and Winooski contact (Figure 7). The composite data from the two wells will be used to identify the stratigraphic distribution and thicknesses of parsequences to make interpretations regarding stratigraphic trends.

In Figure 7 Parasequence sets have been identified and separated by the thin red horizontal lines. The red arrows within the sets indicate decreasing or increasing thickness trends of the cycles of that parasequence set. After examining the data the stratigraphy has been broken into three distinguishable segments identified in Figure 7 as "Intervals". An "Interval" is identified based on the frequency and thickness of parasequence sets and the frequency of the platform carbonate lithology.

The portion of the well identified as "Interval 2" in Figure 7 contains stratigraphy with the most well-developed Type 1 parasequence sets. Interval 2 contains both the thickest single parasequences and thickest parasequence sets seen in the entire composite section. The parasequence sets in Interval 2 are deposited one after another without interruption. Additionally, in Interval 2 there is only one occurrence in the stratigraphy of the platform carbonate. Since the parasequences representing tidal flat progradation are well developed and uninterrupted and because of the low frequency of occurrence of the platform carbonate lithology, Interval 2 is interpreted to represent deposition on a well-developed tidal flat and the generation of accommodation space that was able to keep up with deposition. 


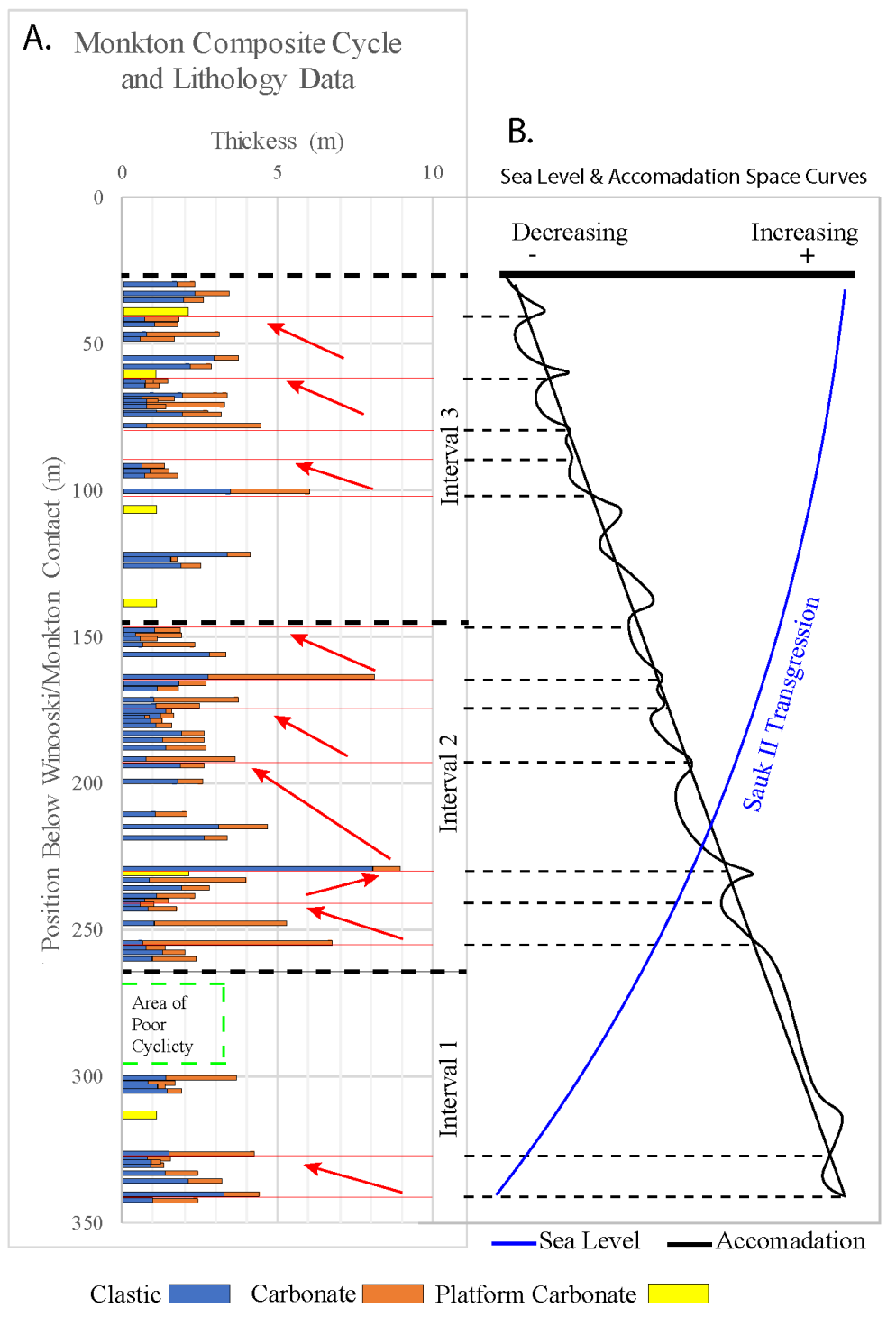

Figure 7. Interpretation of parasequence architecture through the composite Champlainand Fleming wells (A) are plotted (B) versus the Sauk II transgression (blue line) and the interpreted changes in accommodation space (black line). A. Parasequence thickness and stratigraphic position relative to the Monkton/Winooski contact. Colors represent the thickness of clastic and carbonate components of Rahmanian's Type 1 parasequences and of the platform carbonate lithology. The red horizontal lines represent the boundaries between parasequence sets, while the red arrows identify the trends in parasequence thickness within a set. B. Interpreted accommodation space curve (black line) is related to the thinning or thickening of parasequence sets and the presence of the platform carbonate lithology. See text for further discussion.

Interval 3 contains Type 1 parasequence sets like Interval 2, however they are not in succession and the parasequences within them are not as thick. These changes are interpreted to represent decreasing accommodation space because with less space for sediment being created in the nearshore, sediment would be moved further out onto the shelf instead of accumulating on the tidal flat. Interval 3 also contains the highest frequency of the platform carbonate lithology, of- 
ten found separating the parasequence sets. We interpret these carbonates as recording clear water deposition following periodic flooding events that trap siliciclastic sediment on the coastal plain, allowing for a return to clear water carbonate deposition.

Interval 1 contains few repeating parasequence sets and only one instance of the platform carbonate lithology. A large portion of Interval 1, between 265 and 295 meters below the Monkton/Winooski contact, is characterized as poorly cyclic, based on the lack of identifiable parasequences. The gamma values seen in this interval of poor cyclicity are consistent with subtidal sand values. We interpret the lack of cyclicity to the complex depositional processes in the subtidal and the likelihood that the tidal flat is never established, thus the identifiable Type 1 cycles are not being generated.

Figure 7 also shows a generalized sea level curve representing the Sauk II transgression (blue line) and an interpreted accommodation space curve (black line) based on our data. The accommodation space curve was generated by interpreting the bathymetry associated with the parasequences identified in the well log. The cryptalgalaminite lithology (Lithofacies 3) represents sediment which accreted up to/at sea level and thus represents minimum space for additional sediment, in other words, minimal accommodation space, and the sea level rise which followed deposition of this lithofacies created new accommodation space. This sea level rise can also result in deposition of the platform carbonate lithology as a result of clastic sediment trapping on the coastal plain, so the platform carbonate lithofacies represent flooding events. A thinning parasequence set corresponds to a decrease in accommodation space while a thickening set indicates an increase in available accommodation space.

\section{Discussion \& Conclusions}

The successful identification of parasequence sets and lithologies that signify variation in accommodation space through the composite section allows us to describe and interpret changes that occur throughout the Monkton Formation. The interpretations of Intervals I - III in Figure 7 indicate that there is an overall decrease in accommodation space being generated through the Monkton stratigraphy. Though the Monkton was being deposited during the overall transgression at the start of Sauk II, on this portion of the Iapetus shelf the ability to generate accommodation space decreased over time. Since in the case of the Monkton Formation changes in sea level were the primary control on accommodation space generation, these results would conclude that the rate of sea level rise changed through deposition. The combination of relative sea level rise during Sauk II and decreasing accommodation space can only be generated by a decrease in the rate of sea level rise during Monkton Deposition.

As discussed in [39], trends in accommodation space through a unit were a useful tool for interpreting the systems tract it formed in, and by extrapolation, how overall sea level was changing. [39] described a highstand system tract as 
commonly containing progradational deposits that formed when sediment accumulation exceeded the rate of increase in accommodation space. However, progradational deposits can also form during a transgressive systems tract when the rate of sediment accumulation exceeds the rate of increase in accommodation space. Because our data indicate a loss in accommodation space over time, progradation of the tidal flat deposits that characterize the Monkton Formation and the decreasing trend in accommodation space suggests that transgressive system tract deposition is coming to an end as highstand conditions are approached (Figure $8(\mathrm{~A})$ ). If this were the case, we would also expect to see the onset of clear water carbonate deposition marking the transition to a highstand systems tract. No such interval is present within the Monkton. However, the contact between the Monkton and Winooski Formations, with the shoreline at its maximum landward position, could be interpreted to represent this transition. If the Monkton was deposited, as we think, entirely in the transgressive

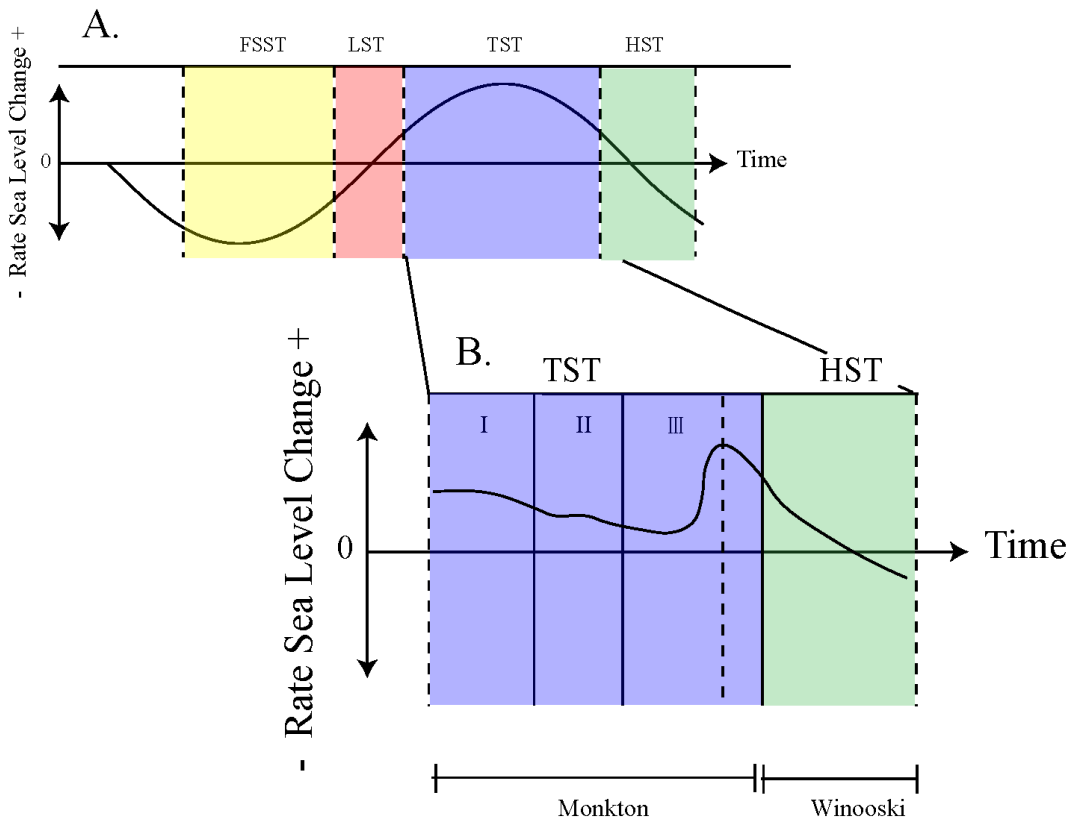

Figure 8. Rate in sea level change curves for systems tracts model (A) and interpretation of sea level changes through Monkton deposition (B). For both curves the $\mathrm{x}$ axis represents time while the $\mathrm{y}$ the rate in sea level change. Any values above 0 on the $\mathrm{Y}$ axis would represent sea level rise, just at varying rates. (A.) modified from [40] shows the predicted rate in sea level change during falling stand systems tract (FSST), lowstand systems tract (LST), transgressive systems tract (TST) and highstand systems tract (HST). The sea level curve in (B.) shows the how rates have changed over Monkton and Winooski deposition. The area shaded purple shows where the TST is and the green shaded areas is where HST is believed to have occurred. Looking at (B.) the curve through Intervals I-III it is overall decreasing. This decreasing rate would indicate a decreasing generation of accommodation space. There is a dashed line at the end of Interval III because according to our projections of the Winooski Monkton contact there is a portion of Monkton stratigraphy above it not represented by well log data. The interval between Winooski deposition and Interval III is believed to contain a rapid rate in sea level rise, marking the maximum flooding surface and the transition to HST. 
systems tract, then the decreasing accommodation space generation documented in this unit would represent a decreasing rate in sea level rise within the transgression (Figure 8). Following this decreasing sea level rise, Monkton deposition ceases, possibly due to a rapid increase in sea level at the end of the transgression system tract, marking the beginning of the Winooski Dolostone deposition. This transition marks the start of the highstand systems tract, represented by the onset of clear water carbonate deposition and of the Winooski Dolostone.

\section{Conflicts of Interest}

The authors declare no conflicts of interest regarding the publication of this paper.

\section{References}

[1] Van Wagoner, J.C. (1995) Overview of Sequence Stratigraphy of Foreland Basin Deposits: Terminology, Summary of Papers, and Glossary of Sequence Stratigraphy. In: Van Wagoner, J.C. and Bertram, G.T., Eds., Sequence Stratigraphy of Foreland Basin Deposits: Outcrop and Subsurface Examples from the Cretaceous of North America, American Association of Petroleum Geologists, Tulsa, Vol. 64, 9-21.

[2] Posamentier, H.W. and Vail, P.R. (1988) Eustatic Controls on Clastic Deposition. II. Sequence and Systems Tract Models. In: Wilgus, C.K., Hastings, B.S., St. Kendall, C.G.C., Posamentier, H., Ross, C.A. and Van Wagoner, J., Eds., Sea Level Changes. An Integrated Approach, Society for Sedimentary Geology, Tulsa, Vol. 42, 125-154. https://doi.org/10.2110/pec.88.01.0125

[3] Palmer, A.R. and James, N.P. (1980) The Hawke Bay Event: A Circum-Iapetus Regression near the Lower-Middle Cambrian Boundary. Memoir-Department of Geological Sciences, Virginia Polytechnic Institute, Blacksburg, Vol. 2, 15-18.

[4] Rahmanian, V. (1981) Transition from Carbonate to Siliciclastic Tidal Flat Sedimentation in the Lower Cambrian Monkton Formation, West Central Vermont. The Green Mountain Geologist, 7, 20-21.

[5] Cady, W.M. (1945) Stratigraphy and Structure of West-Central Vermont. Geological Society of America Bulletin, 56, 515-588. https://doi.org/10.1130/0016-7606(1945)56[515:SASOWV]2.0.CO;2

[6] Speyer, S. (1983) Subtidal and Intertidal Clastic Sedimentation in a Lower Cambrian Sequence; Monkton Quartzite, Northwestern Vermont. Northeastern Geology, 5, 29-39.

[7] Kim, J., Romanowicz, E. and Mehrtens, C. (2013) Using Deep Bedrock Well Logs to Constrain Stratigraphic and Structural Problems in Vermont. Proceedings of NGWA Conference on Groundwater in Fractured Rock and Sediments, Middlebury, VT, 3 September 2013.

[8] Bond, G.C. (1997) New Constraints on Rodinia Breakup Ages from Revised Tectonic Subsidence Curves. Geological Society of America Abstracts with Programs, 29, 280.

[9] Li, Z.-X., Evans, D.A. and Halverson, G.P. (2013) Neoproterozoic Glaciations in a Revised Global Palaeogeography from the Breakup of Rodinia to the Assembly of Gondwanaland. Sedimentary Geology, 294, 219-232. https://doi.org/10.1016/j.sedgeo.2013.05.016

[10] Kumarapeli, P.H., Dunning, G.R. and Stearn, C.W. (1989) Age of the Tibbit Hill 
Formation and Its Implications on the Timing of Iapetan Rifting. Program with Abstracts-Geological Association of Canada; Mineralogical Association of Canada. Joint Annual Meeting, 14, 125-125.

[11] Thomas, W.A. (1977) Evolution of Appalachian-Ouachita Salients and Recesses from Reentrants and Promontories in the Continental Margin. American Journal of Science, 277, 1233-1278. https://doi.org/10.2475/ajs.277.10.1233

[12] Kay, G.M. (1942) Ottawa-Bonnechere Graben and Lake Ontario Homocline. Bulletin of the Geological Society of America, 53, 585-646. https://doi.org/10.1130/GSAB-53-585

[13] Dorsey, R.J. and Stanley, R.S. (1983) Bedrock Geology of the Milton Quadrangle, Northwestern Vermont. Vermont Geological Survey, Montpelier, VT.

[14] Shaw, A.B. (1958) Stratigraphy and Structure of the Saint Albans Area, Northwestern Vermont. Geological Society of America Bulletin, 69, 519-567. https://doi.org/10.1130/0016-7606(1958)69[519:SASOTS]2.0.CO;2

[15] Stanley, R.F. (1999) The Champlain Thrust Fault at Lone Rock Point. Proceedings of Annual Meeting New England Intercollegiate Geological Conference, 91 st Annual Meeting, Burlington, VT, 16 October 1999, 359-364.

[16] Ratcliffe, N.M., Stanley, R.S., Gale, M.H. and Thompson, P.J. (2011) Bedrock Geologic Map of Vermont. U.S. Geological Survey Scientific Investigations Map 3184, Scale 1:100,000, 3 Sheets.

[17] Schuchert, C. (1933) Cambrian and Ordovician Stratigraphy of Northwestern Vermont. American Journal of Science, 149, 353-381. https://doi.org/10.2475/ajs.s5-25.149.353

[18] Schuchert, C. (1937) Cambrian and Ordovician of Northwestern Vermont. Bulletin of the Geological Society of America, 48, 1001-1078. https://doi.org/10.1130/GSAB-48-1001

[19] Mehrtens, C.J. and Gregory, G. (1984) An Occurrence of Salterella Conulata Clark in the Dunham Dolomite (Lower Cambrian) of Northwestern Vermont and Its Stratigraphic Significance. Journal of Paleontology, 58, 1143-1150.

[20] Palmer, A.R. and Holland, C.H. (1971) The Cambrian of the Appalachian and Eastern New England Regions, Eastern United States. Lower Paleozoic Rocks of the World. Cambrian of the New World, 1, 169-217.

[21] Sloss, L. (1963) Sequences in the Cratonic Interior of North America. Geological Society of America Bulletin, 74, 91-114. https://doi.org/10.1130/0016-7606(1963)74[93:SITCIO]2.0.CO;2

[22] James, N.P., Botsford, J.W. and Williams, S.H. (1987) Allochthonous Slope Sequence at Lobster Cove Head: Evidence for a Complex Middle Ordovician Platform Margin in Western Newfoundland. Canadian Journal of Earth Sciences, 24, 1199-1211. https://doi.org/10.1139/e87-115

[23] Palmer, A. and Taylor, M. (1981) Subdivision of the Sauk Sequence. 2nd International Symposium on the Cambrian System, US Geological Survey, Open-File Report, 81-743.

[24] Mitchum, R. and Van Wagoner, J.C. (1990) High-Frequency Sequences and Eustatic Cycles in the Gulf of Mexico Basin. Proceedings Sequence Stratigraphy as an $E_{X^{-}}$ ploration Tool: Concepts and Practices in the Gulf Coast. Gulf Coast Section SEPM, Houston, TX, 2-5 June 1991, 257-267. https://doi.org/10.5724/gcs.90.11.0257

[25] Raine, R.J. and Smith, M.P. (2012) Sequence Stratigraphy of the Scottish Laurentian Margin and Recognition of the Sauk Megasequence. In: Derby, J.T., Fritz, R.D., 
Longacre, S.A., Morgan, W.A. and Sternbach, C.A., Eds., The Great American Carbonate Bank. The Geology and Economic Resources of the Cambrian-Ordovician Sauk Megasequence of Laurentia, AAPG Memoir 98, 575-596.

[26] Landing, E., Benus, A.P. and Whitney, P.R. (1992) Early and Early Middle Ordovician Continental Slope Deposition: Shale Cycles and Sandstones in the New York Promontory and Quebec Reentrant Reentrant Region. New York State Museum, New York, Bulletin No. 474.

[27] Goldberg, J. and Mehrtens, C. (1998) Depositional Environment and Sequence Stratigraphy Interpretation of the Lower Middle Cambrian Monkton Quartzite, Vermont. Northeastern Geology and Environmental Sciences, 20, 11-27.

[28] Van Wagoner, J.C., Mitchum, R.M., Campion, K.M. and Rahmanian, V.D. (1990) Siliciclastic Sequence Stratigraphy in Well Logs, Cores, and Outcrops: Concepts for High-Resolution Correlation of Time and Facies. American Association of Petroleum Geologists, Tulsa.

[29] Van Wagoner, J., Posamentier, H., Mitchum, R., Vail, P., Sarg, J., Loutit, T. and Hardenbol, J. (1988) An Overview of the Fundamentals of Sequence Stratigraphy and Key Definitions. In: Wilgus, C.K., Hastings, B.S., Kendall, C.G.St.C., Posamentier, H.W., Ross, C.A., Van Wagoner, J.C., Eds., Sea Level Changes-An Integrated Approach, SEPM Special Publication 42, 39-45.

[30] Beerbower, J.R. (1964) Cyclothems and Cyclic Depositional Mechanisms in Alluvial Plain Sedimentation. Kansas Geological Survey Bulletin, 169, 31-32.

[31] Cecil, C.B. (2003) The Concept of Autocyclic and Allocyclic Controls on Sedimentation and Stratigraphy, Emphasizing the Climatic Variable. SEPM Special Publication No. 77.

[32] Maguire, H.C., Mehrtens, C.J., Kim, J. and Romanowicz, E. (2018) Data Processing for Two Well Logs in Burlington, VT. Vermont Geological Survey, Open-File Report 2018.

[33] Czubek, J.A. (1986) Quantitative Interpretation of Gamma-Ray Logs in Presence of Random Noise. SPWLA 27 th Annual Logging Symposium, Houston, 9-13 June 1986, 25.

[34] Doveton, J.H. (1994) Geological Log Interpretation. SEPM (Society for Sedimentary Geology) Short Course, No. 29.

[35] Mount Sopris Instruments (2008) 2PGA-1000 POLY-GAMMA PROBE Manual. 12.

[36] Cannon, S. (2015) Petrophysics: A Practical Guide. John Wiley \& Sons, New York.

[37] Gadeken, L.L., Jacobson, L.A. and Merchant, G.A. (1997) Method for Filtering Gamma Ray Well logging Tool Response to Enhance Vertical Detail While Suppressing Statistical Noise. U.S. Patent 5672867.

[38] Theys, P. (1999) Log Data Acquisition and Quality Control. Editions Technip, Paris, $330 \mathrm{p}$.

[39] Posamentier, H.W. and Allen, G.P. (1999) Siliciclastic Sequence Stratigraphy: Concepts and Applications. SEPM Concepts in Sedimentology and Paleontology Vol. 7, 210.

[40] Catuneanu, O. (2002) Sequence Stratigraphy of Clastic Systems: Concepts, Merits, and Pitfalls. Journal of African Earth Sciences, 35, 1-43. https://doi.org/10.1016/S0899-5362(02)00004-0 